Jurnal Indonesia Sosial Teknologi: p-ISSN: 2723 - 6609

e-ISSN : 2745-5254

Vol. 2, No. 9 September 2021

\title{
KINERJA APARATUR SIPIL NEGARA DI KANTOR KECAMATAN CIGALONTANG KABUPATEN TASIKMALAYA
}

\author{
Tedi Sukmana Harun \\ STISIP Tasikmalaya \\ Email: tedisukmanaharun@gmail.com
}

\begin{abstract}
Abstrak
Kinerja Aparatur Sipil Negara di Kantor Kecamatan Cigalontang Kabupaten Tasikmalaya masih memiliki masalah yaitu: 1) Kurang disiplin terhadap waktu kerja, 2) Adanya tumpang tindih pelaksanaan tugas pokok dan fungsi oleh pegawai, dan 3) Pelaksanaan pelayanan E-KTP belum sesuai dengan standar operasional prosedur. Tujuan penelitian ini adalah Untuk mengetahui bagaimanakah Kinerja Aparatur Sipil Negara di Kantor Kecamatan Cigalontang Kabupaten Tasikmalaya. Metode penelitian yang penulis gunakan adalah metode penelitian deskriptif dengan pendekatan kualitatif, teknik pengumpulan datanya yaitu observasi (pengamatan), wawancara, dokumentasi, dan triangulasi. Penentuan informan penelitian menggunakan teknik Purposive Sampling. Teknik pengolahan dan analisis data dengan reduksi data, penyajian data, dan penarikan kesimpulan. Hasil penelitian menunjukan bahwa: 1) Responsivitas ASN kurang responsif. Hal tersebut dapat diketahui dari: (a) Kemampuan ASN dalam memberikan pelayanan administratif masih minim; (b) Kemampuan ASN dalam penggunaan teknologi dan informasi masih minim; (c) Banyaknya keluhan dari masyarakat tentang kurang responsifnya pegawai dalam melakukan pelayanan administratif maupun teknis; 2) Responsibilitas Aparatur Sipil Negara adalah kurang responsibel. Hal tersebut dapat diketahui dari: a) Belum sesuainya pelaksanaan jam kerja Aparatur Sipil Negara; dan b) Pelaksanaan standar operasional prosedur yang belum sesuai. 3) Kualitas Layanan Aparatur Sipil Negara adalah kurang berkualitas, masyarakat kurang puas terhadap pelayanan; 4) Produktivitas Aparatur Sipil Negara kurang produktif, yaitu kurang jelasnya informasi pelayanan, dan kurang cepat dan tanggapnya pelayanan terutama dalam pengoperasian komputer; dan 5) Akuntabilitas Aparatur Sipil Negara dinilai kurang akuntabeldan efektif. Kesimpulannya kinerja aparatur sipilnegara di kantor kecamatan cigalontang belum efektif.
\end{abstract}

Kata kunci: Kinerja; Aparatur Sipil Negara; Kecamatan Cigalontang

\section{Abstract}

The performance of the State Civil Apparatus at the Cigalontang District Office, Tasikmalaya Regency still has problems, namely: 1) Lack of discipline in working time, 2) There is overlap in the implementation of main tasks and functions by employees, and 3) The implementation of E-KTP services is not in accordance with standard operating procedures. . The purpose of this study was to find out how the performance of the State Civil Apparatus at the Cigalontang District Office, Tasikmalaya Regency. The research method that the author uses is a descriptive 
research method with a qualitative approach, the data collection techniques are observation, interviews, documentation, and triangulation. Determination of research informants usingtechnique purposive sampling. Data processing and analysis techniques with data reduction, data presentation, and drawing conclusions. The results of the study show that: 1) ASN responsiveness is less responsive. This can be seen from: (a) ASN's ability to provide administrative services is still minimal; $(b)$ The ability of ASN in the use of technology and information is still minimal; (c) The number of complaints from the public about the lack of responsiveness of employees in performing administrative and technical services; 2) Responsibility of the State Civil Apparatus is less responsible. This can be seen from: a) The implementation of the working hours of the State Civil Apparatus is not yet appropriate; and $b$ ) Improper implementation of standard operating procedures. 3) The quality of the service of the State Civil Apparatus is of low quality, the community is not satisfied with the service; 4) Productivity of the State Civil Apparatus is less productive, namely the lack of clear information on services, and less fast and responsive services, especially in computer operations; and 5) Accountability of the State Civil Apparatus is considered less accountable and effective. In conclusion, the performance of the state civil apparatus in the Cigalontang sub-district office has not been effective.

Keyword : Performance; State Civil Apparatus; Cigalontang District

\section{Pendahuluan}

Salah satu fungsi pemerintah adalah menyelenggarakan kegiatan pembangunan dan pelayanan sebagai bentuk dari tugas umum pemerintah untuk mewujudkan kesejahteraan masyarakat. Birokrasi merupakan instrumen pemerintah untuk mewujudkan pelayanan publik yang efisien, efektif, berkeadilan, transparan, dan akuntabel. Hal ini berarti untuk mampu melaksanakan fungsi pemerintahan dengan baik maka organisasi birokrasi harus profesional, aspiratif dan memiliki daya tanggap yang tinggi terhadap tuntutan masyarakat yang dilayani agar masyarakat pengguna jasa merasa puas terhadap pelayanan yang diterimanya.

Indonesia merupakan Negara Berkembang dan menjadi salah satu Negara dengan birokrasi terburuk di Asia, menurut Political and Economic Risk Consultancy (PERC). Political and Economic Risk Consultancy (PERC), di awal tahun 2020 telah melakukan sebuah survey, review, dan pemeringkatan terhadap sistem birokrasi di 12 Negara di Asia. Survey ini dilakukan dengan melakukan wawancara pada 1.373 expatriat (tenaga kerja asing) executif tingkat menengah dan senior (PERC), 2020).

Tabel 1. Peringkat Kualitas Birokrasi Tahun 2020

\begin{tabular}{|c|c|c|}
\hline No. & Negara & Skor Integritas \\
\hline 1. & India & 9,41 \\
\hline 2. & Indonesia & 8,59 \\
\hline 3. & Filipina & 8.37 \\
\hline 4. & Vietnam & 8,13 \\
\hline 5. & China & 7,93 \\
\hline
\end{tabular}




\begin{tabular}{cll}
\hline 6. & Malaysia & 6,97 \\
\hline 7. & Taiwan & 6,60 \\
\hline 8. & Jepang & 6,57 \\
\hline 9. & Korea Selatan & 6,13 \\
\hline 10. & Thailand & 5,53 \\
\hline 11. & Hongkong & 3,49 \\
\hline 12. & Singapura & 2,53 \\
\hline & Sura
\end{tabular}

Sumber: Political and Economic Risk Consultancy (PERC)

Buruknya kualitas birokrasi di Indonesia merupakan indikasi bahwa kinerja birokrasi di Indonesia semakin buruk dan semakin korup karena dengan besarnya skor yang dimiliki, semakin buruk kualitas birokrasi di suatu negara. Birokrasi di Indonesia dalan tahun 2020 hanya lebih baik dibandingkan dengan India. Indonesia menjadi peringkat kedua Negara dengan kualitas birokrasi terburuk.

Aparatur Sipil Negara yang selanjutnya disebut ASN adalah profesi bagi Pegawai Negeri Sipil dan Pegawai Pemerintah dengan perjanjian kerja yang bekerja pada instansi Pemerintahan. Aparatur Sipil Negara terdiri dari Pengawai Negeri Sipil (PNS) dan Pegawai Pemerintah dengan Perjanjian Kerja (PPPK) yang diangkat oleh Pejabat Pembina Kepegawaian dan diserahi tugas dalam suatu jabatan Pemerintahan atau diserahi tugas umum Pemerintahan dan Pembangunan Nasional melalui pelaksanaan kebijakan dan pelayanan publik profesional bebas dari intervensi politik, serta bersih dari KKN (Korupsi, Kolusi dan Nepotisme). Sesuai dengan perannya Aparatur Sipil Negara harus memberikan hasil kerja (kinerja) yang baik dalam perannya sebagai perencana dan pengawas penyelenggaraan tugas umum Pemerintahan dan Pembangunan Nasional melalui pelaksanaan kebijakan dan pelayanan publik yang profesional.

Berdasarkan Undang-Undang Republik Indonesia Nomor 5 Tahun 2014 tentang Aparatur Sipil Negara, bahwa untuk mewujudkan Aparatur Sipil Negara sebagai bagian dari reformasi birokrasi, perlu ditetapkan Aparatur Sipil Negara sebagai profesi yang memiliki kewajiban mengelola dan mengembangkan dirinya dan wajib mempertanggungjawabkan kinerjanya dengan menerapkan prinsip merit dalam pelaksanaan manajemen Aparatur Sipil Negara. Citra birokrasi pemerintahan secara keseluruhan akan banyak ditentukan oleh kinerja organisasi tersebut.

Indonesia, memiliki Pegawai Negeri Sipil yang banyak mendapatkan pendidikan dan pelatihan secara rutin. Namun, tidak jarang ada PNS yang sudah bekerja lebih dari 8 tahun, tetapi pendidikan yang didapat baru pra jabatan. Pendidikan tersebut memang wajib bagi Calon Pegawai Negeri Sipil ketika akan diangkat menjadi Pegawai Negeri Sipil.

Kantor Kecamatan Cigalontang merupakan salah satu Kecamatan yang ada di Kabupaten Tasikmalaya yang memiliki potensi daerah yang sangat baik dalam bidang pertanian, dan tanaman buah-buahan seperti kopi dan lainya. Penetapan Kinerja Kantor Kecamatan Cigalontang Kabupaten Tasikmalaya dalam rangka mewujudkan pemerintahan yang efektif, transparan, akuntabel dan berorientasi kepada hasil. Rencara 
kinerja yang telah ditetapkan merupakan tolak ukur keberhasilan organisasi dan menjadi dasar penilaian dalam evaluasi akuntabilitas kinerja pada akhir tahun anggaran.

Berdasarkan observasi penulis di lokasi penelitian, ditemukan berbagai permasalaan terkait kinerja Aparatur Sipil Negara yang ada di Kecamatan Cigalontang Kabupaten Tasikmalaya, diantaranya adalah sebagai berikut:

1. Kurang disiplin terhadap waktu kerja, yaitu banyaknya pegawai yang datang terlambat dan pulang lebih awal dari waktu yang telah di tentukan, hal tersebut diatur dalam Keputusan Presiden Nomor 68 Tahun 1995 tentang Hari Kerja Di Lingkungan Lembaga Pemerintah yang menyebutkan bahwa "Jam kerja efektif dalam lima hari kerja adalah 37,5 jam, dan ditetapkan sebagai berikut: a. Hari Senin sampai dengan Hari Kamis Jam 07:30-16:00 Waktu istirahat: jam 12:00-13:00. b. Hari Jum'at: Jam 07:30-16:30 Waktu istirahat: Jam 11:30-13:00."

Contoh: datang terlambat yaitu lebih dari jam 08:00 WIB, dan pulang lebih awal yaitu jam 15:00 WIB.

Sesuai dengan teori yang digunakan yaitu teori menurut (Dwiyanto dalam Rina, 2021) yang menjelaskan bahwa: indikator kinerja dengan dimensi "Responsibilitas adalah kemampuan yang menunjukkan tingkat kesesuaian antara penyelenggaraan dengan hukum dan peraturan dan prosedur yang telah ditetapkan." Jadi dapat diketahui bahwa terdapat kesenjangan antara fakta dilapangan dengan peraturan, yaitu dari kedisiplinan waktu kerja pegawai.

2. Adanya tumpang tindih pelaksanaan tugas pokok dan fungsi oleh pegawai di Kecamatan Cigalontang Kabupaten Tasikmalaya;

Di Kecamatan Cigalontang, penulis memperoleh informasi dari Camat di Kecamatan Cigalontang yang menyebutkan bahwa: "Dalam pelaksanaan kerja masing-masing pegawai sering kali terjadi tumpang tindih pekerjaan, hal tersebut dikarenakan sumber daya manusia pegawai yang rendah.” Jadi berdasarkan hasil observasi tersebut, maka dapat diketahui bahwa dalam pelaksanaan tugas pokok dan fungsi masing-masing pegawai belum dilaksanakan sesuai dengan Peraturan Bupati Nomor 81 Tahun 2016 tentang Rincian Tugas dan Fungsi Perangkat Daerah Kecamatan.

3. Pelaksanaan pelayanan E-KTP di Kecamatan Cigalontang belum sesuai dengan standar operasional prosedur dalam proses pembuatan E-KTP; Sesuai dengan standar operasional prosedur pelayanan E-KTP di Kecamatan harus ada Petugas Pendukung Pelayanan dan Operator Kecamatan, tapi pada kenyataannya di Kecamatan Cigalontang Operator Kecamatan bertindak sekaligus sebagai Petugas Pendukung Pelayanan. Hal tersebut menyebabkan pelayanan yang ada di Kecamatan Cigalontang menjadi tidak efektif dan efisien.

Berikut penulis menyajikan perbandingan penelitan yang digunakan oleh penulis sekarang dengan peneliti terdahulu adalah sebagai berikut:

Membahas tentang kinerja terdapat penelitian terdahulu dan tentunya terdapat perbedaan penelitian yang penulis sekarang lakukan terhadap penelitian yang dilakukan oleh peneliti terdahulu adalah sebagai berikut: 
Penelitian terdahulu pertama oleh (Hutasoit, 2016) perbedaannya adalah pada tujuan penelitian. Tujuan penelitian peneliti terdahulu adalah (1) Untuk Mengetahui dan Mendiskripsikan Kinerja Pegawai Negeri Sipil Pada Kantor Kecamatan Palaran Kota Samarinda, dan (2) Untuk Mendeskripsikan Faktor Penghambat Kinerja Pegawai Negeri Sipil Pada Kantor Kecamatan Palaran Kota Samarinda, sedangkan penelitian penulis Untuk Mengetahui Kinerja Aparatur Sipil Negara Di Kantor Kecamatan Cigalontang Kabupaten Tasikmalaya (Dandan, 2020). Teori yang digunakan adalah sama yaitu menggunakan teori menurut (Dwiyanto, 2021) dengan dimensi: (1) Produktivitas, (2) Kualitas Pelayanan, (3) Responsivitas, (4) Responsibilitas, dan (5) Akuntabilitas. Teknik pengumpulan data yang dilakukan oleh peneliti terdahulu adalah dengan Triangulasi (gabungan), Penelitian Kepustakaan (Library Research), dan Penelitian Lapangan (Field Work Research) yang terdiri dari Observasi, Informan (wawancara), dan dokumentasi, sedangkan penelitian penulis menggunakan teknik pengumpulan data yaitu observasi partisipasi pasif, interview/wawancara terstruktur, dokumentasi, dan triangulasi sumber.

Kedua oleh (Mandasari et al., 2017) Kinerja Aparatur Sipil Negara (ASN) dalam Meningkatkan Kualitas Birokrasi di Kelurahan Bontang Baru Kota Bontang. Penelitian ini mendeskripsikan kinerja ASN melalui beberapa indikator yang meliputi produktivitas, kualitas layanan, responsivitas, responsibilitas, dan akuntabilitas -Hasil penelitian menunjukkan bahwa Kelurahan Bontang baru berusaha menerapakan teknologi infirmasi dalam meningkatkan pelayanan baik dari segi produktivitas dan kualitas. Selain itu kelurahan juga berusaha untuk melakukan strategi jemput bola ntuk meningkatkan responsivitas dan bertanggungjawab untuk mematuhi standar pelayanan yang telah ditentukan serta menjalankan tugas pokoknya sesuai dengan aturan -Hasil penelitian juga menunjukkan bahwa kelurahan perlu meningkatkan kinerjanya dalam konteks sosialisasi pelayanan kepada masyarakat dan penyediaan fasilitas pelayanan yang memadai kepada masyarakat

Penelitian tersebut tentunya relevan dengan penelitian penulis dalam segi variabelnya dan tentunya terdapat persamaan dan perbedaan di dalamnya. Persamaan penelitian yang dilakukan oleh penulis dengan penelitian tersebut adalah dalam hal variabel kinerja, metode yang di gunakan. Adapun perbedaannya adalah dalam hal teori yang digunakan, waktu dan tema atau fokus penelitian serta hasil dan kesimpulanya, namun dianggap relevan dengan penelitian penulis. Namun yabg penulis bidik sebagi kebaharuanya terletak pada reformasi ASN agar menjadi efektif dan memberikan dampak positif bagi pemerintahan.

Membahas tentang kinerja tentunya akan membahas konsepnya terlebih dahulu, kinerja perlu dilakukan dengan hati-hati, karena akan menentukan kinerja aparatur dan kinerja organisasi, sejalan dengan hal tersebut pengertian kinerja menurut (Supandi, 2021), adalah:

"Konsep kinerja merupakan singkatan dari kinetika energi kerja yang padanannya dalam bahasa inggris adalah performance. Istilah performance sering di Indonesiakan sebagai performa. Kinerja adalah keluaran yang dihasilkan oleh 
fungsi-fungsi atau indikator-indikator suatu pekerjaan atau suatu profesi dalam waktu tertentu."

Kinerja adalah tentang melakukan pekerjaan tersebut. Kinerja adalah tentang apa yang dikerjakan dan bagaimana cara mengerjakannya. Kinerja merupakan hasil pekerjaan yang mempunyai hubungan kuat dengan tujuan strategis organisasi, kepuasan konsumen dan memberikan kontribusi ekonomi.

Berdasarkan pengertian di atas bahwa hasil yang dicapai oleh seseorang Aparatur Sipil Negara (ASN) secara terukur dalam pekerjaannya dan dilaksanakan sesuai dengan kemampuan yang dimiliki, dan tugas yang telah ditentukan. Aparatur Sipil Negara (ASN) dalam memberdayakan dan memaksimalkan suatu kinerja, diperlukan pengetahuan yang luas dalam melaksanakan tugasnya, sehingga menghasilkan apa yang menjadi tujuan utama. Pengertian lain menurut Kinerja dalam bahasa Inggris disebut juga dengan job performance atau actual performance, yang merupakan tingkat keberhasilan pegawai dalam menyelesaikan pekerjaannya. Kinerja bukan merupakan karakteristik individu, seperti bakat, atau kemampuan, namun merupakan perwujudan dari bakat atau kemampuan itu sendiri. Kinerja adalah hasil kerja dan perilaku kerja yang telah dicapai dalam menyelesaikan tugas dan tanggung jawab yang diberikan dalam suatu periode tertentu. Kinerja merupakan suatu fungsi dari motivasi dan kemampuan. Untuk menyelesaikan tugas atau pekerjaan seseorang sepatutnya dimiliki derajat kesediaan dan tingkat kemampuan tertentu.

(Kasmir, 2014) menyatakan untuk memperkuat bahwa kinerja individu adalah dasar kinerja organisasi yang sangat dipengaruhi oleh karakteristik individu, motivasi individu, pengharapan, dan penilaian yang dilakukan oleh manajemen terhadap pencapaian hasil kerja individu.

Sedangkan menurut ( Colquitt dalam Kasmir, 2014) kinerja ditentukan oleh 3 faktor, yaitu :

a. Kinerja tugas (task performence).

b. Perilaku kesetiaan (citizenship behavior) sebagai perilaku positif.

c. Perilaku produktif tandingan (counter productive behavior) sebagai perilaku negatif.

(Ruky, 2016) menguatkan melalui definisi faktor yang berpengaruh langsung terhadap tingkat pencapaian kinerja organisasi adalah sebagai berikut:

1. Teknologi yang meliputi peralatan kerja dan metode kerja yang digunakan untuk menghasilkan produk dan jasa yang dihasilkan oleh organisasi. Semakin berkualitas teknologi yang digunakan, maka akan semakin tinggi tingkat kinerja organisasi tersebut.

2. Kualitas input atau material yang digunakan oleh organisasi.

3. Kualitas lingkungan fisik yang meliputi keselamatan kerja, penataan ruanganm dan kebersihan.

4. Budaya organisasi sebagai pola tingkah laku dan pola kerja yang ada dalam organisasi yang bersangkutan. 
5. Kepemimpinan sebagai upaya untuk mengendalikan anggota organisasi agar bekerja sesuai dengan standar dan tujuan organisasi.

6. Pengelolaan sumber daya manusia yang meliputi aspek kompensasi, imbalan, promosi dan lainnya.

Kinerja dalam lingkup Organisasi Publik yaitu hasil kerja yang dicapai oleh seorang Aparatur Sipil Negara (ASN) untuk melakukan suatu pekerjaan dan dapat dievaluasi tingkat kinerjanya. Kinerja Aparatur Sipil Negara (ASN) harus dapat ditentukan dengan target yang dicapai selama periode waktu yang telah ditentukan dalam organisasi (Kreitner \& Kinicki, 2005). Berhasil tidaknya tujuan dan cita-cita dalam Organisai Pemerintahan tergantung bagaimana proses kinerja itu dilaksanakan. Kinerja tidak terlepas dari faktor-faktor yang mempengaruhi. Berikut faktor-faktor yang mempengaruhi kinerja

Berbagai macam jenis pekerjaan yang dilakukan oleh karyawan tentunya membutuhkan kriteria yang jelas, karena masing-masing pekerjaan tentunya mempunyai standar yang berbeda-beda tentang pencapaian hasilnya. Menurut (Kasmir, 2014) menyebutkan dalam praktiknya kinerja dibagi ke dalam dua jenis yaitu kinerja individu dan kinerja organisasi. Kinerja individu merupakan kinerja yang dihasilkan oleh seseorang, sedangkan kinerja organisasi merupakan kinerja perusahaan secara keseluruhan. Selanjutnya menurut ( Robbins dalam Sumual, 2017) penilaian kinerja terdiri dari pendekatan sikap, pendekatan perilaku, pendekatan hasil, pendekatan kontingensi. Adapun penjelasan mengenai jenis penilaian tersebut adalah: 1) Pendekatan sikap, pendekatan ini menyangkut penilaian terhadap sifat atau karakteristik individu. 2) Pendekatan perilaku, melihat bagaimana orang berperilaku. Kemampuan orang untuk bertahan meningkat apabila penilaian kinerja didukung oleh tingkat perilaku kerja. 3) Pendekatan hasil, perilaku memfokuskan pada proses, pendekatan hasil memfokuskan pada produk atau hasil usaha seseorang atau yang diselesaikan individu. 4) Pengekatan kontingensi, pendekatan ini selalu dicocokkan dengan situasi tertentu yang sedang berkembang. Pendekatan sikap cocok ketika harus membuat keputusan promosi untuk calon yang mempunyai pekerjaan tidak sama

Berdasarkan pengertian di atas kinerja Aparatur Sipil Negara (ASN) adalah dipengaruhi faktor yang dipengaruhi beberapa pendukung dan penghambat dalam menjalankan pencapaian suatu kinerja yang maksimal, faktor tersebut meliputi faktor yang berasal dari intern maupun ekstern. Suatu kinerja dapat dinilai, apakah sudah berjalan sesuai dengan tujuan yang direncanakan, untuk itu perlu diadakan suatu evaluasi kinerja.

Selanjutnya menurut ( Greenberg \& Baron dalam Sumual, 2017) menjelaskan bahwa "Penilaian kinerja atau evaluasi dapat dipergunakan untuk sejumlah kepentingan organisasi. Manajemen menggunakan evaluasi untuk mengambil keputusan tentang sumber daya manusia. Penilaian memberikan masukan untuk kepentingan penting seperti promosi, mutase dan pemberhentian".

Sedangkan menurut untuk mengukur kinerja organisasi pemerintah secara komperehensif yaitu sebagai berikut: 
"Dalam mengukur kinerja organisasi pemerintah (birokrasi publik) disesuaikan dengan tugas dan fungsi yang dijalankan. Selanjutnya dikatakan bahwa indikator kinerja yang komperehensif karena mencakup dimensi-dimensi: kualitas layanan, produktivitas, responsivitas, responsibilitas, dan akuntabilitas."

Selain itu, indikator kinerja yang diungkapkan oleh (Dwiyanto, dalam Rina, 2018) yaitu:

1. Responsivitas

Responsivitas adalah kemampuan organisasi publik dalam mengenali kebutuhan masyarakat dalam menyelenggarakan pelayanan publik.

2. Responsibilitas

Responsibilitas adalah kemampuan yang menunjukkan tingkat kesesuaian antara penyelenggaraan pemerintahan dengan hukum dan peraturan dan prosedur yang telah ditetapkan.

3. Kualitas Layanan

Kualitas layanan adalah kemampuan organisasi pelayanan publik untuk memberikan pelayanan yang dapat memuaskan para pengguna jasa baik melalui pelayanan teknis maupun pelayanan administrasi. Isu mengenai kualitas layanan cenderung menjadi semakin penting dalam menjelaskan kinerja organisasi pelayanan publik.

4. Produktivitas

Produktivitas pada umumnya dipahami sebagai rasio antara input dan output, artinya perbandingan sejauh mana upaya yang dilakukan dengan hasil yang diperolehnya dalam periode tertentu. Hasil yang dicapai dapat berupa barang.

5. Akuntabilitas

Akuntabilitas publik menunjukkan pada seberapa besar kebijakan dan kegiatan organisasi publik tunduk pada pejabat politik yang dipilih oleh rakyat.

Tujuan penelitian sebagai berikut: Untuk Mengetahui Kinerja Aparatur Sipil Negara Di Kantor Kecamatan Cigalontang Kabupaten Tasikmalaya.

Manfaat dari penelitian ini dapat dikemukakan menjadi tiga sisi, pertama dapat memberikan manfaat secara teoritis, sekurang-kurangnya dapat berguna sebagai sumbangan pemikiran bagi dunia pendidikan. Kedua diharapkan dapat menambah studi kepustakaan khususnya Ilmu Pemerintahan guna penelitan lebih lanjut. Ketiga diharapkan dapat memberikan kontribusi berupa ide dan gagasan serta masukan dalam upaya meningkatkan Kinerja Aparatur Sipil Negara yang ada di Kecamatan Cigalontang berdasarkan pada landasan teoritik empirik.

\section{Metode Penelitian}

Metode yang digunakan dalam Penelitian ini ialah pendekatan kualitatif, sedang datanya terdiri Data Primer dan Data Sekunder (Sugiyono, 2012)

Penentuan informan penelitian dalam penelitian ini penulis menggunakan teknik purposive sampling (Indrawan \& Yaniawati, 2016). Penulis menentukan informan penelitiannya adalah sebagai berikut:

1. Camat Kecamatan Cigalontang Kabupaten Tasikmalaya, 
2. Sekretaris Kecamatan Cigalontang Kabupaten Tasikmalaya,

3. Kasubbag Umum dan Kepegawaian Kecamatan Cigalontang Kabupaten Tasikmalaya,

4. Pengelola Umum dan Kepegawaian Kecamatan Cigalontang Kabupaten Tasikmalaya,

5. Sebagian Masyarakat di Kecamatan Cigalontang Kabupaten Tasikmalaya.

Teknik pengumpulan data ialah dengan melakukan pengamatan Observation), Wawancara, Dokumentasi dan Triangulasi. Pengolahan data dan analisis datanya yaitu reduksi data (Data Reduction), Penyajian Data (Data Display) dan Penarikan Simpulan/ Verifikasi (Conclussion Drawing/verification)."

Lokasi penelitian dilaksanakan di Kecamatan Cigalontang Kabupaten Tasikmalaya.Penelitian ini dilakukan dalam waktu 7 (Tujuh bulan)

\section{Hasil dan Pembahasan}

Kinerja (prestasi kerja) adalah suatu hasil kerja yang dicapai seseorang dalam melaksanakan tugas-tugas yang dibebankan kepadanya yang didasarkan atas kecakapan, pengalaman dan kesungguhan serta waktu. Pembahasan mengenai Kinerja Aparatur Sipil Negara di Kecamatan Cigalontang Kabupaten Tasikmalaya dianalisis melalui lima dimensi yaitu: Responsivitas, Responsibilitas, Kualitas Layanan, Produktivitas, dan Akuntabilitas. Adapun penjelasan hasil penelitian ke lima dimensi yaitu sebagai berikut:

\section{Responsivitas}

Responsivitas adalah kemampuan Aparatur Sipil Negara (ASN) dalam mengenali kebutuhan masyarakat dalam menyelenggarakan pelayanan publik. Hal ini dapat dilihat dari Kemampuan Aparatur Sipil Negara dalam pelayanan administratif, Kemampuan Aparatur Sipil Negara dalam penggunaan teknologi dan informasi, Kemampuan Aparatur Sipil Negara dalam berkomunikasi dengan baik secara lisan, Kemampuan Aparatur Sipil Negara dalam berkomunikasi dengan baik secara tulisan.

Kemampuan Aparatur Sipil Negara dalam pelayanan administratif merupakan sebuah acuan tercapai atau tidaknya target yang ditentukan oleh pimpinan kepada stafnya, juga penggunaan waktu yang efektif dalam sebuah pekerjaan, serta pembagian kerja yang seimbang dan merata kepada jajaran staf dalam memberikan pelayanan administratif.

Berdasarkan hasil penelitian dapat diketahui bahwa kemampuan Aparatur Sipil Negara yang ada di Kecamatan Cigalontang adalah berbeda-beda. Hal tersebut sesuai dengan kompetensi dan keahlian masing-masing pegawai, tidak semua pegawai dapat mengoperasikan komputer, sehingga hal tersebut dapat menghambat terhadap proses pelayanan yang diberikan.

Berdasarkan penjelasan dari beberapa informan melalui penelitian, maka dapat disimpulkan bahwa pada dimensi responsivitas adalah kurang responsif. Hal tersebut dapat diketahui dari: 1) Kemampuan ASN dalam memberikan pelayanan administratif masih minim yaitu pelaksanaan tugas pokok dan fungsi masing-masing pegawai belum dapat dilaksanakan oleh masing-masing bidang; 2) Kemampuan ASN dalam 
penggunaan teknologi dan informasi masih minim yaitu tidak semua pegawai dapat mengoperasikan komputer; 3) Banyaknya keluhan dari masyarakat tentang kurang responsifnya pegawai dalam melakukan pelayanan administratif maupun teknis.

\section{Responsibilitas}

Responsibilitas adalah kemampuan Aparatur Sipil Negara (ASN) yang menunjukkan tingkat kesesuaian antara penyelenggaraan pemerintahan dengan hukum dan peraturan dan prosedur yang telah ditetapkan. Hal ini dapat dilihat dari kesesuaian jam kerja Aparatur Sipil Negara terhadap peraturan/Undang-Undang, Kesesuaian standar operasional prosedur pelayanan terhadap masyarakat, dan Kesesuaian biaya yang dikeluarkan oleh masyarakat dalam melakukan pelayanan.

Berikut penulis sajikan hasil penelitian dengan narasumber mengenai Responsibilitas yang dihasilkan oleh Aparatur Sipil Negara di Kecamatan Cigalontang Kabupaten Tasikmalaya dengan parameternya: Jam Kerja Aparatur Sipil Negara, kesesuaian pelayanan terhadap Standard Operasional Prosedure, dan biaya yang dipungut terhadap masyarakat dalam melakukan pelayanan, antara lain:

a) Kesesuaian jam kerja pegawai di Kecamatan Cigalontang Kabupaten Tasikmalaya adalah belum sesuai dengan ketentuan yang berlaku, yaitu masuk jam 08:00 WIB - 15:00 WIB hal ini menunjukan bahwa jam kerja ASN di Kecamatan Cigalontang Kabupaten Tasikmalaya belum sesuai dengan ketentuan jam kerja ASN di Kabupaten Tasikmalaya.

b) Pembahasan tentang parameter kedua dari dimensi responsibilitas yaitu kesesuaian standar operasional prosedur pelayanan terhadap masyarakat dapat diketahui sebagai berikut: responsibilitas pegawai di Kecamatan Cigalontang adalah kurang responsibel. Hal tersebut dapat diketahui dari pelaksanaan pelayanan yang ada belum sesuai dengan standar operasional prosedur pelayanan, dan pelayanan yang diberikan terhadap masyarakat tidak oleh bidangnya masing-masing. Hasil penelitian ini dapat dianalisa bahwa Rensponsibilitas Aparatur Sipil Negara di Kecamatan Cigalontang Kabupaten Tasikmalaya adalah kurang responsibel, artinya Aparatur Sipil Negara yang ada di Kecamatan Cigalontang Kabupaten Tasikmalaya belum melaksanakan tugas pokok dan fungsinya masing-masing.

c) Pembahasan hasil wawancara untuk parameter yang ketiga pada dimensi responsibilitas adalah kesesuaian biaya yang dikeluarkan oleh masyarakat dalam melakukan pelayanan, yaitu dapat diketahui sebagai berikut: "kesesuaian biaya yang dikeluarkan masyarakat adalah telah sesuai dengan ketentuan yang berlaku dalam pelayanan terhadap masyarakat, pihak Kecamatan tidak pernah memungut biaya diluar ketentuan yang berlaku dalam pelayanan". maka dapat diketahui bahwa tidak ada pungutan liar yang dilakukan oleh pihak Kecamatan Cigalontang terhadap masyarakat.

Jadi berdasarkan penjelasan dari beberapa informan di atas, maka dapat diketahui bahwa responsibilitas kerja Aparatur Sipil Negara yang ada di Kecamatan Cigalontang Kabupaten Tasikmalaya adalah kurang responsibel, hal tersebut dapat 
diketahui dari: 1) Belum sesuai nya pelaksanaan jam kerja Aparatur Sipil Negara yang ada di Kecamatan Cigalontang Kabupaten Tasikmalaya yaitu masih banyak Aparatur Sipil Negara yang datang terlambat dari waktu yang telah ditentukan; dan 2) Pelaksanaan standar operasional prosedur Aparatur Sipil Negara yang ada di Kecamatan Cigalontang Kabupaten Tasikmalaya juga belum sesuai, hal tersebut dapat diketahui dari tumpang tindih pelaksanaan tugas pokok dan fungsi Aparatur Sipil Negara yang ada di Kecamatan Cigalontang Kabupaten Tasikmalaya

\section{Kualitas Layanan}

Sejauh mana Kualitas Layanan Aparatur Sipil Negara di Kecamatan Cigalontang Kabupaten Tasikmalaya. Kualitas layanan adalah kemampuan Aparatur Sipil Negara (ASN) untuk memberikan pelayanan yang dapat memuaskan para pengguna jasa baik melalui pelayanan teknis maupun pelayanan administrasi. Hal ini dapat dilihat dari: Kepuasan masyarakat dalam pelayanan teknis Aparatur Sipil Negara, Kepuasan masyarakat dalam pelayanan administrasi Aparatur Sipil Negara, Keramahan Aparatur Sipil Negara dalam melakukan pelayanan, dan Kesopanan Aparatur Sipil Negara dalam melakukan pelayanan.

Berdasarkan hasilpenelitian melalui beberapa informan di atas mengenai kualitas layanan Aparatur Sipil Negara di Kecamatan Cigalontang Kabupaten Tasikmalaya adalah kurang berkualitas. Kurang berkualitasnya pelayanan yang diberikan Aparatur Sipil Negara dapat diketahui dari banyaknya masyarakat yang merasa kurang puas terhadap pelayanan administratif maupun pelayanan teknis yang diberikan oleh Aparatur Sipil Negara, selain itu Aparatur Sipil Negara yang ada di Kecamatan Cigalontang Kabupaten Tasikmalaya kurang ramah dan kurang sopan dalam memberikan pelayanan terhadap masyarakat, hal tersebut dapat diketahui dari sikap Aparatur Sipil Negara di Kecamatan Cigalontang Kabupaten Tasikmalaya yang kurang peduli terhadap masyarakat yang datang ke Kantor Kecamatan.

\section{Produktivitas}

Produktivitas pada umumnya dipahami sebagai rasio antara input dan output, artinya perbandingan sejauh mana upaya yang dilakukan oleh Aparatur Sipil Negara (ASN) dengan hasil yang diperolehnya dalam periode tertentu. Hasil yang dicapai dapat berupa barang. Hal ini dapat dilihat dari

a) Kecepatan pelayanan yang dilakukan oleh Aparatur Sipil Negara;

b) Ketepatan pelayanan yang dilakukan oleh Aparatur Sipil Negara;

c) Kejelasan informasi yang diberikan oleh Aparatur Sipil Negara dalam pelayanan administratif; dan

d) Kejelasan informasi yang diberikan oleh Aparatur Sipil Negara dalam pelayanan teknis.

Pegawai dituntut untuk memiliki semangat dalam melaksanakan tugas-tugas baru dan dalam memperbesar tanggung jawabnya. Karena tanggung jawab dalam pekerjaan menentukan tercapai tidaknya target yang sudah ditentukan oleh pimpinan.

Berdasarkan hasilpenelitian menunjukan bahwa produktivitas Aparatur Sipil Negara di Kecamatan Cigalontang Kabupaten Tasikmalaya adalah kurang produktif, 
hal tersebut dapat diketahui dari kurang jelasnya informasi pelayanan yang ada di Kecamatan Cigalontang Kabupaten Tasikmalaya, selain itu Aparatur Sipil Negara di Kecamatan Cigalontang Kabupaten Tasikmalaya kurang cepat dan tanggap dalam memberikan pelayanan terutama dalam pengoperasian komputer".

\section{Akuntabilitas}

Akuntabilitas publik menunjukkan pada seberapa besar kebijakan dan kegiatan Aparatur Sipil Negara (ASN) tunduk pada pejabat politik yang dipilih oleh rakyat. Hal ini dapat dilihat dari: Ketaatan Aparatur Sipil Negara dalam berpakaian, Kejujuran Aparatur Sipil Negara dalam melakukan pelayanan teknis, dan Kejujuran Aparatur Sipil Negara dalam melakukan pelayanan administratif.

Berdasarkan hasilpenelitian ditemukan bahwa Aparatur Sipil Negara di Kecamatan Cigalontang Kabupaten Tasikmalaya dinilai kurang bertanggung jawab terhadap masyarakat dalam memberikan pelayanan, hal tersebut dapat diketahui dari kurangnya perhatian dari pegawai terhadap masyarakat yang datang ke Kantor Kecamatan. Hasil analisis penullis menyimpulkan bahwa Aparatur Sipil Negara dinilai masih kurang bertanggung jawab dalam memberikan pelayanan terhadap masyarakat. Hal tersebut menyebabkan kurangnya kepercayaan masyarakat terhadap pegawai dan masyarakat yang ada di Kecamatan Cigalontang pun menjadi enggan.

Dapat disimpulkan bahwa akuntabilitas Aparatur Sipil Negara di Kecamatan Cigalontang Kabupaten Tasikmalaya dinilai masih kurang, hal tersebut dapat diketahui dari belum semua Aparatur Sipil Negara taat dalam berpakaian, belum semua Aparatur Sipil Negara bertanggung jawab dalam manajerial kerja, dan belum semua Aparatur Sipil Negara bertanggung jawab dalam memberikan pelayanan terhadap masyarakat.

\section{Kesimpulan}

Berdasarkan hasil pemaparan dan pembahasan pada uraian di atas tentang masalah dan temuan-temuan di lapangan mengenai penelitian Kinerja Aparatur Sipil Negara di Kecamatan Cigalontang Kabupaten Tasikmalaya dengan berdasarkan 5 (lima) dimensi, yang terdiri dari: 1) Responsivitas; 2) Responsibilitas; 3) Kualitas Layanan; 4) Produktivitas; dan 5) Akuntabilitas, dapat diketahui sebagai berikut:

1. Responsivitas Aparatur Sipil Negara di Kecamatan Cigalontang Kabupaten Tasikmalaya adalah kurang responsif. Hal tersebut dapat diketahui dari: 1) Kemampuan ASN dalam memberikan pelayanan administratif masih minim; 2) Kemampuan ASN dalam penggunaan teknologi dan informasi masih minim

2. Responsibilitas Aparatur Sipil Negara di Kecamatan Cigalontang Kabupaten Tasikmalaya adalah kurang responsibel: 1) Belum sesuai nya pelaksanaan jam kerja Aparatur Sipil Negara yang ada di Kecamatan Cigalontang Kabupaten Tasikmalaya. 2) Pelaksanaan standar operasional prosedur Aparatur Sipil Negara yang ada di Kecamatan Cigalontang Kabupaten Tasikmalaya juga belum sesuai,

3. Kualitas Layanan Aparatur Sipil Negara di Kecamatan Cigalontang Kabupaten Tasikmalaya adalah kurang berkualitas. 
Tedi Sukmana Harun

4. Produktivitas Aparatur Sipil Negara di Kecamatan Cigalontang Kabupaten Tasikmalaya kurang produktif.

5. Akuntabilitas Aparatur Sipil Negara di Kecamatan Cigalontang Kabupaten Tasikmalaya adalah kurang akuntabel. 
Kinerja Aparatur Sipil Negara di Kantor Kecamatan Cigalontang Kabupaten Tasikmalaya

\section{Bibliografi}

(PERC), Political and Economic Risk Consultancy. (2020). Political and Economic Risk Consultancy (PERC), (2020) survey, review, dan pemeringkatan terhadap sistem birokrasi di 12 Negara di Asia.

Dandan, Haryono dan. (2020). Kinerja pegawai di Sekretariat Daerah Kota Tasikmalaya.

Dwiyanto, Agus. (2021). Mewujudkan good governance melalui pelayanan publik. UGM PRESS.

Hutasoit, Nova Selvia. (2016). Kinerja Pegawai Negeri Sipil Pada Kantor Kecamatan Palaran Kota Samarinda. EJournal Administrasi Negara, 4(2), 2016.

Indrawan, Rully, \& Yaniawati, R. Poppy. (2016). Metodologi Penelitian: Kuantitatif, Kualitatif dan Campuran untuk Manajemen, Pembangunan, dan Pendidikan.

Kreitner, Robert, \& Kinicki, Angelo. (2005). Perilaku Organisasi, buku 1. Edisi Kelima, Jakarta: Salemba Empat.

Mandasari, Pika, Idris, H. Adam, Si, M., Dyastari, Letizia, Sos, S., \& Si, M. (2017). KINERJA APARATUR SIPIL NEGARA (ASN) DALAM MENINGKATKAN KUALITAS BIROKRASI DI KELURAHAN BONTANG BARU KOTA BONTANG.

Modal, Profitabilitas Dan Likuiditas Pada Struktur. (2014). Kasmir.(2014). Analisis laporan keuangan, Edisi 7, PT. RajaGrafindo Persada, Jakarta Sugiono, A \& Untung, E.(2009). Panduan Praktis Dasar Analisa Laporan Keuangan, Edisi 2, PT. Grasindo, Anggota Ikapi, Jakarta. Sitanggang, JP.(2013). Manajemen Keuangan Pe. Jurnal Akuntansi Universitas Udayana, 9, 788-882.

Ruky, Achmad S. (2001). Performance management system: Panduan praktis untuk merancang dan meraih kinerja prima. Gramedia Pustaka Utama, Jakarta.

Sugiyono. (2012). Metode Penelitian Kuantitatif. 46-57.

Sumual, Tinneke Evie Meggy. (2017). Manajemen Sumber Daya Manusia. Edisi Revisi. Surabaya: CV. RA De. Rozarie.

Supandi, Muhammad Zaki Fadli. (2021). Pemberdayaan Ekonomi Masyarakat Oleh Bank Sampah Gemah Ripah Bantul Perspektif Maqasid Syari'ah.

Undang-Undang Republik Indonesia Nomor 5 Tahun 2014 tentang Aparatur Sipil Negara

Peraturan Bupati Nomor 81 Tahun 2016 tentang Rincian Tugas dan Fungsi Perangkat Daerah Kecamatan 